\title{
The Dynamics of Exchange Rate and Stock Return Before and After the Fed Policy Normalization: Evidence from Fragile Five Countries
}

\author{
Arsya Javidiar ${ }^{1}$, Irwan Adi Ekaputra ${ }^{2 *}$ \\ ${ }^{1,2}$ Faculty of Economics and Business, Universitas Indonesia, Depok 16424, Indonesia
}

\section{A B S T R A C T}

This research aims to examine whether the Fed policy normalization affects correlations between exchange rate and stock return in each Fragile Five countries: Indonesia, Brazil, India, Turkey, and South Africa. Using daily data, we investigate and divide our study into two periods: before Fed funds rate normalization (2013-2015) and after normalization (2016-2018). We utilize the Granger causality test, Vector Autoregression (VAR), and Dynamic Conditional Correlation-Multivariate GARCH (DCC-MGARCH) in our analysis. Granger test results show relationship dissimilarities between exchange rates and stock returns in Indonesia, India, and Turkey after the Fed normalization. Additionally, we learn that exchange rates tend to lead stock returns in these three countries. Furthermore, the results of the DCC-MGARCH show a positive dynamic correlation between stock returns of different markets. The results also show positive dynamic correlations between the exchange rates of each country.

(C) 2019 IJBS, All rights reserved.

\section{A R T I C L E I N F O}

\section{Keywords:}

Fragile Five,

Exchange Rate,

Stock Return,

VAR, DCC MGARCH
*Corresponding Author E-mail: irwan.adi@ui.ac.id

Copyright $(2019$ Authors. This is an open access article distributed under the Creative Commons Attribution License, which permits unrestricted use, distribution, and reproduction in any medium, provided the original work is properly cited.

\section{INTRODUCTION}

A decade has passed, since the Global Financial Crisis (GFC) in 2008 triggering liquidity problems in the United States economy. As an attempt to stimulate the economy, the Fed maintains a lowinterest rate. In December 2008, the Fed cut its interest rate to the range between $0 \%$ and $0.25 \%$, and maintain the low-interest rates for a while. To help jumpstart the economy, the Fed combines interest rate reduction and the Quantitative
Easing (QE) policy to increase bank liquidity in the US. With swelling liquidity, investors channel liquidity to emerging markets through investments.

When the US economy improves after the crisis, the Fed started to implement a tapering off policy in May 2013, and drafts a policy normalization plan that they implement since December 2015. FOMC (The Federal Open Market 
Committee) indicates that there are two primary components in the policy normalization plan. Firstly, the Fed gradually increases the range of Fed funds rate target to a more reasonable level. Secondly, the Fed gradually reduces ownership of Federal Reserve securities.

Stock markets in developing countries tend to react negatively due to the Fed policy normalization plan. If the Fed continues to raise interest rates through the normalization of the policy, foreign investors will respond by withdrawing funds and transferring their investment to the country of origin (capital flight), which in turn affects the attitude of domestic investors to divert their funds to the safer investments (flight to quality). The desolate stock market, in turn, will lead to the stock market index plunge and the currency weakening.

Information about the Fed funds rate is one of the bases for decision making in stock investment. Besides, investors also need to observe the exchange rate against the US Dollar, given that the exchange rate also influences the development of export-import and commodity prices in each country.

When the value of the domestic currency depreciates, or the US Dollar strengthens, investors tend to convert local currency into USD, rather than investing in stocks and long-term investments in domestic securities. As a result, an outflow occurs. Vice versa, the appreciation of the domestic currency encourages investors to be interested in domestic stock investments. The exchange rate depreciation that is being experienced by Indonesia from 2016 to the third quarter of 2018 is allegedly due to some external sentiments, such as, the Trump Effect, the Fed interest rate increase plan, and the US-China trade war that has not subsided since mid-2018.

In this study, the authors are interested in analyzing whether the Fed policy normalization has a similar impact on the exchange rate and stock price index in five emerging markets dubbed the 'Fragile Five': Brazil, Turkey, India,
South Africa, and Indonesia. The term Fragile Five appears in early August 2013, when James K. Lord, an analyst from Morgan Stanley, explained the research related to the investment risk in Fragile Five countries. This term then spreads rapidly, especially among investors who were increasingly concerned about their shareholding in developing countries (New York Times, January 28, 2014).

The Fragile Five are developing countries whose economies are vulnerable because they are highly dependent on foreign capital. Moreover, these five countries experienced a sharp increase in foreign capital outflows after the Fed implements tapering off or retracts monetary stimulus in 2013. The five countries all experience a current account deficit resulting in a sharp decline of their local currencies in the second half of 2013 (South China Morning Post, September 6, 2018).

The integration of the global stock exchange makes the dynamics of stock prices influence each other. According to Al Nasser and Hajilee (2015), financial market integration today tends to eliminate barriers to allocate capital more efficiently. If the stock market has a correlation and integration relationship that is getting stronger with the international market, investment in these countries will become increasingly high risk. Markowitz (1952) also suggests that diversification can still be done to minimize portfolio risk as long as the correlation coefficient is still less than 1 .

Rodoni (2008) added that the essential factor when investors try to diversify their portfolio is the low level of correlation between each return. The lower the correlation coefficient, the higher the benefits from portfolio diversification. Based on this understanding, it is beneficial to diversify outside the investor's home country.

In the previous study, Tuna (2016) found that there was a cointegration relationship between the stock exchanges of Fragile Five countries using the Maki Cointegration Test method using monthly stock price data from the period June 2006 to 
July 2015. This study also provides portfolio diversification recommendations through the long-term approach.

Valadkhani and Chancarat (2009) find out whether there are influences between 15 international stock indices (Argentina, Australia, Brazil, Germany, Hong Kong, Indonesia, Japan, Korea, Malaysia, the Philippines, Russia, Singapore, Taiwan, the United Kingdom, and the United States) and Macroeconomic variables on stock indices in Thailand using OLS and ARCH-GARCH regression methods. The study period consists of two periods: before and after the 1997 Asian crisis. Their study finds that international stock indices that are geographically far enough do not have a direct impact on the stock index in Thailand.

Meanwhile, Dash and Mallick (2011) try to find the contagion effect on the Indian stock exchange from the financial crisis in the United States. They use the NASDAQ and BSE (India) indices during the period 2002 to 2009, and dynamic conditional correlation (DCC) multivariate GARCH to measure the time-varying co-movement. From this study, they conclude that there is a transmission between the US and Indian stock markets, indicated by a significant increase in the average correlation coefficient between the two stock exchanges during the crisis period.

Bala Sani and Hassan (2018) found a unidirectional relationship between exchange rates and stock markets in Nigeria, where the exchange rate affects stock price index returns. To clarify the transmission of the negative relations between exchange rates and stock price index returns, Anggitawati and Ekaputra (2018) find that the exchange rate of the Indonesian Rupiah /US Dollar and Net Foreign Inflows shows a negative relation. When Indonesian Rupiah depreciates, foreign investors tend to sell Indonesian stock portfolios.

In this research, we intend to examine whether the normalization of the Fed Funds rate policy affects the causality relations between the exchange rate and the stock return of each Fragile Five countries. Then, we continue this research by analyzing how strong the level of dynamic correlation between stock returns so that it is expected to provide a reference to the portfolio diversification in the Fragile Five countries. Also, this study will analyze how strong the dynamic correlation between the five countries' exchange rates, so that it can provide an idea of how far each country's exchange rate depreciation can affect each other amid global uncertainties after the Fed hikes interest rates in the policy normalization.

\section{RESEARCH METHODS}

In this research, we use a quantitative empirical study approach. The variables used in this study consist of the daily stock returns of Fragile Five countries: (1) JKSE (Jakarta Composite Index), (2) BVSP (Sao Paulo SE Bovespa Index), (3) XU100 (Borsa Istanbul 100 Index), (4) BSESN (S \& P BSE Sensex Index), and (5) FTJ203 (FTSE /JSE SA All Share Index).

Furthermore, we also use daily exchange rate returns from Fragile Five countries: (1) IDR/ USD (Indonesian Rupiah /US Dollar), (2) BRL / USD (Brazilian Real/US Dollar), (3) TRY/USD (Turkish Lira/US Dollar), (4) INR/USD (Indian Rupee/US Dollar), and (5) ZAR/USD (South African Rand/US Dollar). We collect all the data from Thomson Reuters datastream. Then, we calculate each stock return and exchange rate data with the following formula:

$$
\operatorname{Return}_{t}=\frac{P_{t}-P_{t-1}}{P_{t-1}}
$$

We complete the analysis by testing the data using Granger-causality Test, VAR (Vector Autoregression), and DCC (Dynamic Conditional Correlation) GARCH methods. VAR analysis is used to find relationships between variables through the test of Granger-causality, and analyze how the influence of exchange rate depreciation on stock index returns in five countries. The VAR test conducted in each of the Fragile Five countries (Indonesia, Brazil, Turkey, India, and South Africa) in the prior period (2013:1-2015:12) 
and after the Fed funds rate policy normalization (2016:1-2018:10). Time series testing using VAR follows the following specification:

$$
y_{t}=\alpha+\beta_{y} y_{t-1}+\beta_{2} y_{t-2}+\cdots+\beta_{p} y_{t-p}+\varepsilon_{t}
$$

Meanwhile, we use DCC GARCH method to determine the existence of a dynamic correlation between stock index returns and exchange rates in five countries, and then to find out whether the Fed policy normalization has an impact on the relationship of dynamic correlation between Fragile Five countries. Engle (2002) modified the DCC model by allowing the R correlation matrix to vary every time. The following equation defines the DCC GARCH model:

$$
\begin{gathered}
r_{t}=\mu_{t}+a_{t} \\
a_{t}=H_{t}^{1 / 2} Z_{t} \\
H_{t}=D_{t} R_{t} D_{t}
\end{gathered}
$$

Where $D_{t}$ is $n \times n$, the diagonal matrix of the conditional standard deviation of $\mathrm{a}_{\mathrm{t}}$ time $\mathrm{t}$. Then, $\mathrm{R}_{\mathrm{t}}$ is the matrix $\mathrm{nxn}$ conditional correlation from $a_{t}$ time $t$.

Diagonal matrix element $D_{t}$ is the standard deviation of the univariate GARCH model, which is indicated by the following matrix equation:

$$
\mathbf{D}_{\mathbf{t}}=\left[\begin{array}{cccc}
\sqrt{h_{1 t}} & 0 & \cdots & 0 \\
\vdots & \sqrt{h_{2 t}} & \ddots & \vdots \\
0 & \cdots & \sqrt{h_{n t}} & 0
\end{array}\right]
$$

Where

$$
h_{i t}=\alpha i 0+\sum_{q=1}^{Q i} \alpha_{i q} a_{i t-q}^{2}+\sum_{p=1}^{p i} \beta_{i p} h_{i, t, p}
$$

Meanwhile, $\mathrm{R}_{\mathrm{t}}$ is a conditional (conditional) correlation matrix.

$$
\mathbf{R}_{\mathrm{t}}=\left[\begin{array}{ccccc}
\mathbf{1} & \rho_{12, t} & \rho_{13, t} & \cdots & \rho_{1 n, t} \\
\rho_{12, t} & \mathbf{1} & \rho_{23, t} & \cdots & \rho_{2 n, t} \\
\rho_{13, t} & \rho_{23, t} & \mathbf{1} & \ddots & \vdots \\
\vdots & \vdots & \ddots & \ddots & \rho_{n-1, n, t} \\
\rho_{1 n, t} & \rho_{2 n, t} & \cdots & \rho_{n-1, n, t} & \mathbf{1}
\end{array}\right]
$$

When specifying the shape of $R_{t}$ two requirements must be considered: (1) $H_{t}$ must be positively defined because it is in the form of a covariance matrix. To ensure that $H_{t}$ is positive, then $R_{t}$ must also be positive definite, (2) All elements in the correlation matrix $R_{t}$ must be equal to or less than one. To fulfill the two DCCGARCH model requirements above, $R_{t}$ must be in the form of the following equations:

$$
\begin{gathered}
R_{i t}=Q_{t}^{*-1} Q_{t} Q_{t}^{*-1} \\
Q_{t}=(1-\mathrm{a}-\mathrm{b}) Q+\alpha \varepsilon_{t-1} \varepsilon_{t-1}^{T}+\mathrm{b} Q_{t-1}
\end{gathered}
$$

$Q_{t}$ must be positive definite to ensure that $R_{t}$ is also positive. Then, $\mathrm{a}$ and $\mathrm{b}$ are parameters that determine whether conditional dynamic correlation requirements are met because in order to better ensure that $H_{t}$ is positive, both scalar parameters $\mathrm{a}$ and $\mathrm{b}$ must also be positive and both must meet the requirements of $0 \leq \mathrm{a}+\mathrm{b}<1$. After that, proceed with estimating the correlation coefficient. The correlation structure can be expanded into the general form of the DCC GARCH equation model as follows:

$Q_{t}=\left(1-\sum_{m=1}^{M} a_{\mathrm{m}}-\sum_{n=1} b_{n}\right) \bar{Q}_{t}+\sum_{m=1}^{M} a_{m} a_{t-1} a_{t-1}^{T}+\sum_{n=1}^{N} b_{n} Q_{t-1}$

Several previous GARCH methods have concluded that international correlation is not constant and continues to change dynamically over time. Using 150-year data, Goetzmann et al. (2005) conclude that the correlation between global markets has changed significantly over time. The highest correlation is during the Great Depression at the end of the 19th century, and it reappears at the end of the 20th century.

\section{RESULT AND DISCUSSION}

Before testing time-series data, this study tests the stationarity of the data. This test is also commonly called the stationary stochastic process. The stationary testing method used in this study is ADF (Augmented Dickey-Fuller) at the same level so that the data can be stationary simultaneously.

The results of the ADF stationarity test of each Fragile Five country is presented in Table 1. The data stationarity test at the level degree concludes that all variables in both periods are stationary with a significance level of $\alpha 1 \%, 5 \%$, and $10 \%$. This can be seen from the ADF value, which is higher than the value of MacKinnon Critical Value. Because of all the stock price index 
and the exchange rate of each Fragile Five country are significant at the level degree, the research for each period has fulfilled the requirements to be processed with the Granger causality and VAR methods.

Table 1. Unit Root Test (ADF Test)

\begin{tabular}{|l|c|c|}
\hline \multirow{2}{*}{ Variables } & \multicolumn{2}{|c|}{ Augmented Dickey-Fuller (Level) } \\
\cline { 2 - 3 } & $\begin{array}{c}\text { Before the Fed } \\
\text { Normalization }\end{array}$ & $\begin{array}{c}\text { After the Fed } \\
\text { Normalization }\end{array}$ \\
\hline JKSE & $-22.91907^{* * *}$ & $-23.91476^{* * *}$ \\
\hline BVSP & $-25.36371^{* * *}$ & $-18.85705^{* * *}$ \\
\hline XU100 & $-23.86545^{* * *}$ & $-19.38527^{* * *}$ \\
\hline BSESN & $-22.79707^{* * *}$ & $-21.90129^{* * *}$ \\
\hline FTJ203 & $-25.18369^{* * *}$ & $-18.15456^{* * *}$ \\
\hline IDR/USD & $-14.87475^{* * *}$ & $-24.08421^{* * *}$ \\
\hline BRL/USD & $-26.58758^{* * *}$ & $-26.32872^{* * *}$ \\
\hline TRY/USD & $-25.10590^{* * *}$ & $-21.16752^{* * *}$ \\
\hline INR/USD & $-24.97126^{* * *}$ & $-23.61293^{* * *}$ \\
\hline ZAR/USD & $-26.88628^{* * *}$ & $-22.75755^{* * *}$ \\
\hline
\end{tabular}

${ }^{*}$ significant at $10 \%,{ }^{* *}$ significant at $5 \%,{ }^{* * *}$ significant at $1 \%$.

Table 2. Granger Causality Test Before Fed Funds Rate Normalization

\begin{tabular}{|l|c|c|}
\hline \multicolumn{1}{|c|}{ Null Hypothesis: } & F-Statistic & Prob. \\
\hline $\begin{array}{l}\text { BRL/USD does not Granger Cause } \\
\text { BRAZILBVSP }\end{array}$ & 0.0918 & 0.9123 \\
\hline $\begin{array}{l}\text { BRAZILBVSP does not Granger } \\
\text { Cause BRL/USD }\end{array}$ & 1.3194 & 0.268 \\
\hline $\begin{array}{l}\text { IDR/USD does not Granger } \\
\text { Cause JKSE }\end{array}$ & 1.5051 & 0.2228 \\
\hline $\begin{array}{l}\text { JKSE does not Granger Cause } \\
\text { IDR/USD }\end{array}$ & 1.0394 & 0.3543 \\
\hline $\begin{array}{l}\text { INR/USD does not Granger Cause } \\
\text { INDIABSE }\end{array}$ & 0.2081 & 0.8122 \\
\hline $\begin{array}{l}\text { INDIABSE does not Granger Cause } \\
\text { INR/USD }\end{array}$ & 0.8275 & 0.4376 \\
\hline & 3.6185 & 0.0274 \\
\hline $\begin{array}{l}\text { TRY/USD does not Granger Cause } \\
\text { XU100TURKEY* }\end{array}$ & 3.9296 & 0.0201 \\
\hline $\begin{array}{l}\text { XU100TURKEY does not Granger } \\
\text { Cause TRY/USD* }\end{array}$ & 3.9659 & 0.0194 \\
\hline & 0.57 & 0.5658 \\
\hline $\begin{array}{l}\text { ZAR/USD does not Granger Cause } \\
\text { FTJSAFRICA* }\end{array}$ & $\begin{array}{l}\text { FTJSAFRICA does not Granger } \\
\text { Cause ZAR/USD }\end{array}$ & \\
\hline
\end{tabular}

*Null hypothesis is rejected

Table 2 summarizes the results of the Granger causality test between the stock returns and exchange rate in each country before the Fed policy normalization period (2013-2015). Based on the results of the Granger causality test obtained in table 2, it can be seen that before the normalization of the Fed policy was applied, we found a bidirectional relationship between the stock price index on the Borsa Istanbul, Turkey (XU100) stock exchange and the Turkish Lira / US exchange rate Dollar (TRY / USD), which means the two variables are interconnected. This can be seen from the probability value below $5 \%$ so that the two null hypotheses are rejected.

Meanwhile, we found a unidirectional relationship between South African Rand / US Dollar (ZAR / USD) and South African stock price index (FTSE / JSE South Africa), where ZAR / USD affects the South African stock price index before normalization Fed policy occurs. This can be inferred from the probability value below $5 \%$ so that the null hypothesis which states that there is no relationship between ZAR / USD and the South African stock index is rejected at the $5 \%$ significance level.

Table 3. Granger Causality Test After Fed Funds Rate Normalization

\begin{tabular}{|l|c|c|}
\hline \multicolumn{1}{|c|}{ Null Hypothesis: } & F-Statistic & Prob. \\
\hline $\begin{array}{l}\text { BRL/USD does not Granger Cause } \\
\text { BRAZILBVSP }\end{array}$ & 1.08001 & 0.3403 \\
\hline $\begin{array}{l}\text { BRAZILBVSP does not Granger } \\
\text { Cause BRL/USD }\end{array}$ & 2.74602 & 0.0650 \\
\hline $\begin{array}{l}\text { IDR/USD does not Granger } \\
\text { Cause JKSE* }\end{array}$ & 9.41554 & 0.0022 \\
\hline $\begin{array}{l}\text { JKSE does not Granger Cause } \\
\text { IDR/USD }\end{array}$ & 0.09533 & 0.7576 \\
\hline $\begin{array}{l}\text { INR/USD does not Granger Cause } \\
\text { INDIABSE* }\end{array}$ & 6.05759 & 0.0141 \\
\hline $\begin{array}{l}\text { INDIABSE does not Granger Cause } \\
\text { INR/USD }\end{array}$ & 0.01297 & 0.9094 \\
\hline $\begin{array}{l}\text { TRY/USD does not Granger Cause } \\
\text { XU100TURKEY* }\end{array}$ & 4.16575 & 0.0160 \\
\hline $\begin{array}{l}\text { XU100TURKEY does not Granger } \\
\text { Cause TRY/USD }\end{array}$ & 0.06057 & 0.9412 \\
\hline $\begin{array}{l}\text { FTJJSAFRICA does not Granger } \\
\text { Cause ZAR/USD }\end{array}$ & 0.29443 & 0.5876 \\
\hline
\end{tabular}

*Null hypothesis is rejected 
After that, we conduct the second Granger test to investigate the direction of relations between endogenous variables in each of the Fragile Five countries after the Fed policy normalization was implemented (2016-2018). Table 3 summarizes the results of the Granger causality test between the stock returns and exchange rate in each country after the Fed normalizing its policy. Based on the results of the Granger test in the following period, a unidirectional relationship is found between the stock price index return and the exchange rates of Indonesia, Turkey, and India.

Rupiah / US Dollar (IDR / USD) and Composite Stock Price Index (JKSE) which in the previous period does not have a causality relationship, have a unidirectional relationship after the Fed normalization, where IDR / USD affects JKSE. The null hypothesis, which states that IDR / USD is not related to JKSE, is rejected at the 5\% significance level.

Similar findings are also found in India. The exchange rate of Indian Rupee / US Dollar (INR / USD) and BSE Sensex Index (BSE), which in the previous period does not have a causal relationship, shows unidirectional relationship after the Fed normalization, where INR / USD affects the BSE Sensex. The null hypothesis is rejected at the $5 \%$ significance level.

Then, a unidirectional relationship is also found in Turkish Lira / US Dollar (TRY / USD) exchange rate and BIST stock index (XU100) after the Fed normalization, which in the previous period there is a bidirectional relationship between the two variables. After the Fed normalization, the null hypothesis, which states that TRY/USD does not have a relationship with $\mathrm{Xu} 100$, is also rejected at $\alpha=5 \%$

After making a comparison between before and after normalization of the Fed's policy, this study concludes that Fed fund rate hike has an impact on the causality relations between exchange rates and stock returns in Indonesia, Turkey, and India.
Table 4. VAR Results Between Stock Return and Exchange Rate in Indonesia After Fed Funds Rate Normalization

\begin{tabular}{|c|c|c|}
\hline & $\begin{array}{c}\text { JKSE return } \\
\text { [t-statistic] }\end{array}$ & $\begin{array}{c}\text { IDR/USD } \\
\text { [t-statistic] }\end{array}$ \\
\hline JKSE return (-1) & -0.050533 & -0.005795 \\
\hline & {$[-1.00915]$} & {$[-0.36338]$} \\
\hline JKSE return (-2) & -0.012770 & -0.032113 \\
\hline & {$[-0.25706]$} & {$[-2.02982]$} \\
\hline IDR/USD (-1) & $-0.492042 * * *$ & 0.028827 \\
\hline & {$[-3.14257]$} & {$[0.57810]$} \\
\hline IDR/USD (-2) & 0.056932 & -0.018790 \\
\hline & {$[0.36187]$} & {$[-0.37502]$} \\
\hline Constant & 0.000396 & 0.000169 \\
\hline & {$[0.93677]$} & {$[1.25266]$} \\
\hline
\end{tabular}

${ }^{*}$ significant at $10 \%,{ }^{* *}$ significant at $5 \%,{ }^{* * *}$ significant at $1 \%$.

In the next step, we conduct a VAR test to find out how the exchange rate affects the stock price index in the country affected by the normalization of the Fed policy. The results of unrestricted VAR estimation are shown in Table 4. Based on the results obtained, we can learn that in the period after the Fed normalization, IDR / USD exchange rate has a negative and significant effect on Indonesian stock returns at a significance level of $1 \%, 5 \%$, or $10 \%$.

Subsequent VAR unrestricted tests also found similar results in India after Fed funds rate normalization. Same with Indonesia, after the Fed normalization, INR / USD exchange rate also has a negative and significant effect on stock returns in India at 5\% significance level.

Theoretically, a significant negative effect of the exchange rate on stock price index returns shows that when the currency depreciates, import-oriented company performance will be depressed so that investors will sell their stock then causes a decline in the stock price index.

Table 5. VAR Results Between Stock Return and Exchange Rate in India After Fed Funds Rate Normalization

\begin{tabular}{|c|c|c|}
\hline & $\begin{array}{c}\text { INDIABSE return } \\
\text { [t-statistic] }\end{array}$ & $\begin{array}{c}\text { INR/USD } \\
\text { [t-statistic] }\end{array}$ \\
\hline INDIABSE return (-1) & 0.037774 & -0.001029 \\
\hline & {$[0.72308]$} & {$[-0.05890]$} \\
\hline INDIABSE return (-2) & -0.012787 & -0.021543 \\
\hline & {$[-0.24728]$} & {$[-1.24604]$} \\
\hline INR/USD (-1) & $-0.375889^{* *}$ & 0.041706 \\
\hline
\end{tabular}




\begin{tabular}{|c|c|c|}
\hline & {$[-2.41233]$} & {$[0.80056]$} \\
\hline INR/USD (-2) & 0.034070 & -0.085585 \\
\hline & {$[0.21705]$} & {$[-1.63079]$} \\
\hline Constant & 0.000419 & 0.000198 \\
\hline & {$[1.02477]$} & {$[1.44681]$} \\
\hline
\end{tabular}

*significant at $10 \%,{ }^{* *}$ significant at $5 \%,{ }^{* * *}$ significant at $1 \%$

Furthermore, based on the negative impact between variables in Indonesia and India after the Fed normalization, it can be explained that the Fed funds rate hike is one of the sentiments that cause capital outflows from emerging markets such as Indonesia and India because investors tend to invest their funds in the United States in deposits or bonds with higher interest rates and profit. Capital outflows from these countries result in US Dollar strengthening and give pressure on Rupiah and Rupee exchange rates.

This explanation is in line with the findings of Anggitawati and Ekaputra (2018). They find that the exchange rate of the Rupiah / US Dollar and Net Foreign Inflows has a negative relationship. When Rupiah depreciates, foreign investors tend to sell Indonesian stock portfolios. The surge in selling will contribute to the overall stock price decline.

Meanwhile, we find different results in Turkey stock market after the Fed normalization period. According to VAR estimation results in table 6, Turkish Lira / US Dollar exchange rate has a positive impact on Borsa Istanbul stock return in the second lag. Overall, it means that Turkish Lira depreciation leads to the Turkey stock market appreciation.

Table 6. VAR Results Between Stock Return and Exchange Rate in Turkey After Fed Funds Rate Normalization

\begin{tabular}{|c|c|c|}
\hline & $\begin{array}{c}\text { Xu100 return } \\
\text { [t-statistic] }\end{array}$ & $\begin{array}{c}\text { TRY/USD } \\
\text { [t-statistic] }\end{array}$ \\
\hline Xu100 return (-1) & 0.012712 & -0.013674 \\
\hline & {$[0.19411]$} & {$[-0.31322]$} \\
\hline XU100 return (-2) & -0.021149 & 0.006545 \\
\hline & {$[-0.32460]$} & {$[0.15068]$} \\
\hline TRY/USD (-1) & -0.145201 & 0.120916 \\
\hline & {$[-1.50102]$} & {$[1.87502]$} \\
\hline TRY/USD (-2) & $0.243146^{* *}$ & -0.245961 \\
\hline
\end{tabular}

\begin{tabular}{|c|c|c|}
\hline & {$[2.51450]$} & {$[-3.81556]$} \\
\hline Constant & -0.000525 & 0.001305 \\
\hline & {$[-0.59385]$} & {$[2.21245]$} \\
\hline
\end{tabular}

${ }^{*}$ significant at $10 \%,{ }^{* *}$ significant at $5 \%,{ }^{* * *}$ significant at $1 \%$.

After conducting the Granger causality test and vector autoregression (VAR) method, we continue the analysis to the second phase of the research, DCC MGARCH model. This method is beneficial for estimating the dynamic correlation among variables. So, we use this model in order to see how strong the level of correlation and integration among stock returns in Fragile Five countries. Low, zero or negative correlation coefficient allow investors to manage a portfolio with lower risk than relying solely on investment in a single asset (Reilly and Brown, 2012).

Based on the results shown in Table 7 , the magnitude of the DCC MGARCH coefficient can illustrate how strong the relationship and integration among stock exchanges in Fragile Five countries. From table 7, we can learn that each Fragile Five stock exchange has positive dynamic correlation and significant at $\alpha=5 \%$.

These results indicate that stock markets in developing countries are correlated with each other before and after the Fed policy normalization. Correlation coefficients range from a weak level of 0.149439 (between Indonesia and Brazil) to a moderate level at 0.519872 (between Brazil and South Africa).

After we conduct the DCC MGARCH estimation, we investigate the correlation coefficient movement among markets by arranging them into the graph shown by Figure 1. This graph reflects the development of the dynamic correlation between Fragile Five stock exchanges over the period.

The graph shown in Figure 1 is in line with the DCC output in Table 7, and we learn that there are positive dynamic correlations among the five stock exchanges throughout the period before and after the Fed policy normalization. 
After the Fed funds rate hike at the end of 2015, the correlations among five countries' stock exchanges tend to become increasingly stable.

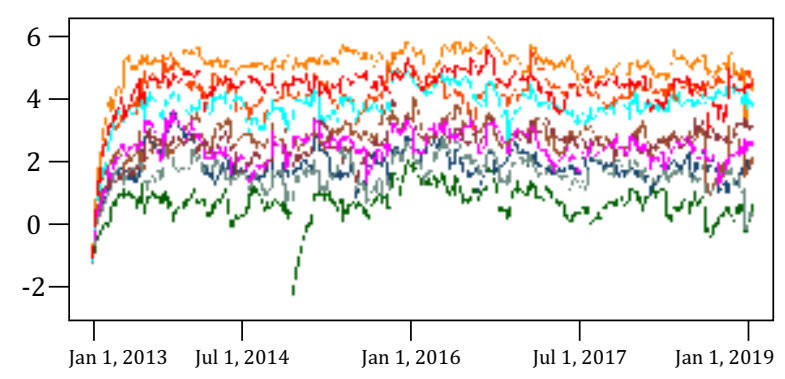

Figure 1. Dynamic Conditional Correlation of Fragile Five stock returns

\begin{tabular}{|ll|}
\hline cor_Indonesia_Brazil & - cor_Indonesia_India \\
- cor_Indonesia_Turkey & - cor_Indonesia_South Africa \\
cor_Brazil_india & - cor_Brazil_turkey \\
cor_Brazil_South Africa & - cor_India_Turley \\
cor_India_South Africa & - cor_Turkey_South Africa \\
\hline
\end{tabular}

Date

Furthermore, the results in Table 8 show the DCC MGARCH coefficient and illustrate how strong the relationship and integration among the foreign exchange markets in Fragile Five countries. Based on this model, we conclude that the Fragile Five exchange rate against the US Dollar overall have a positive dynamic correlation with each other, and significant at the $\alpha=5 \%$.
Table 8. Dynamic Conditional Correlation Between Exchange Rates in Fragile Five Countries

\begin{tabular}{|c|c|c|c|}
\hline \multirow{2}{*}{$\begin{array}{c}\text { Correlation between } \\
\text { Exchange Rates }\end{array}$} & \multicolumn{3}{|c|}{ Overall Period } \\
\cline { 2 - 4 } & Coef. & Std. Error & Prob. \\
\hline Corr(IDR,BRL) & $0.1451773^{*}$ & 0.0419443 & 0.001 \\
\hline Corr(IDR,INR) & $0.4145392^{*}$ & 0.0381295 & 0.000 \\
\hline Corr(IDR,TRY) & $0.1624842^{*}$ & 0.0421462 & 0.000 \\
\hline Corr(IDR,ZAR) & $0.2129730^{*}$ & 0.0427874 & 0.000 \\
\hline Corr(BRL,INR) & $0.2601782^{*}$ & 0.0406095 & 0.000 \\
\hline Corr(BRL,TRY) & $0.3623299^{*}$ & 0.0402080 & 0.000 \\
\hline Corr(BRL,ZAR) & $0.4621608^{*}$ & 0.0389655 & 0.000 \\
\hline Corr(INR,TRY) & $0.3258525^{*}$ & 0.0388505 & 0.000 \\
\hline Corr(INR,ZAR) & $0.3793772^{*}$ & 0.0387620 & 0.000 \\
\hline Corr(TRY,ZAR) & $0.5552229^{*}$ & 0.0372550 & 0.000 \\
\hline
\end{tabular}

*significant at $\alpha=5 \%$

Moreover, a significant correlation coefficient at $5 \%$ ranges from a very low level, at 0.1451773 (between Rupiah and Brazillian Real) to a moderate correlation level, amounting to 0.5552229 (between Turkish Lira and South African Rand). These findings indicate that the currency depreciation occurring in each country have a similar impact on the exchange rate of other five fragile countries, especially since the Fed raised interest rates through policy normalization.

In line with dynamic conditional correlation obtained from the DCC MGARCH method in Table 8, Figure 2 also illustrates the development

Table 7. Dynamic Conditional Correlation Between Stock Returns in Fragile Five Countries

\begin{tabular}{|c|c|c|c|}
\hline \multirow{2}{*}{ Correlation between Stock Returns } & \multicolumn{3}{|c|}{ Overall Period } \\
\cline { 2 - 4 } & Coefficient & Std. Error & 0.000 \\
\hline Corr(Indonesia, Brazil) & $0.1494392^{*}$ & 0.0364358 & 0.000 \\
\hline Corr(Indonesia, India) & $0.4439338^{*}$ & 0.0300291 & 0.000 \\
\hline Corr(Indonesia, Turkey) & $0.2298463^{*}$ & 0.0362454 & 0.000 \\
\hline Corr(Indonesia, SouthAfrica) & $0.3299131^{*}$ & 0.0337776 & 0.000 \\
\hline Corr(Brazil, India) & $0.2374515^{*}$ & 0.0350783 & 0.000 \\
\hline Corr(Brazil, Turkey) & $0.3680411^{*}$ & 0.0317768 & 0.000 \\
\hline Corr(Brazil, SouthAfrica) & $0.5198725^{*}$ & 0.0266493 & 0.000 \\
\hline Corr(India, Turkey) & $0.2965397^{*}$ & 0.0340999 & 0.000 \\
\hline Corr(India, SouthAfrica) & $0.4264110^{*}$ & 0.0305842 & 0.000 \\
\hline
\end{tabular}

*significant at $\alpha=5 \%$ 
positive dynamic correlations among Fragile Five exchange rates over the period. After the Fed normalization implemented at the end of 2015, the correlation coefficients tend to increase, so we find an indication of the higher integration level among five currencies.

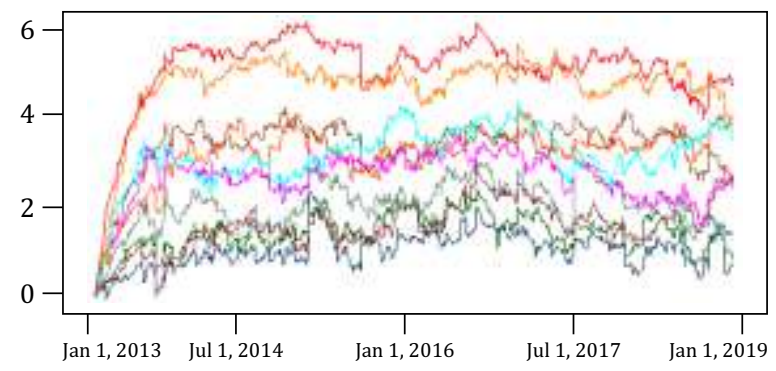

Figure 2. Dynamic Conditional Correlation of Fragile Five exchange rates

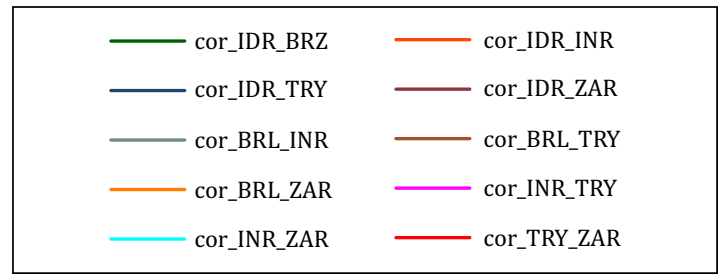

Date

\section{CONCLUSION}

This research consists of two different phases. The first phase begins with the division of the research period into two periods: the period before (2013-2015) and after the normalization of the Fed (2016-2018) policy rate. Firstly, this study utilizes the Granger-causality test and Vector Autoregression (VAR) model to find out which countries respond to the impact of increasing Fed funds rate that transmits to the forex and stock markets. Secondly, we use DCC MGARCH method to identify how strong the level of integration illustrated by the dynamic correlation among stock exchanges and currency markets in the Fragile Five countries (Indonesia, Brazil, India, Turkey, and South Africa).

Based on the results, we find different causality relationships in Indonesia, India, and Turkey after the Fed funds rate normalization. After the normalization, we find that the relations between the exchange rate and the stock return of the three countries change from bi-directional to unidirectional relations. Based on VAR estimation results, local currency exchange rate depreciation hurts stock price returns in Indonesia and India in the post-normalization period. Meanwhile, we find the opposite impact in Turkey. Based on the DCC GARCH test, we find positive dynamic correlation among stock returns in five countries. Besides, the movement of the correlation coefficients among stock markets tend to be more stable after the Fed normalization period. We also find stable dynamic correlations among five exchange rates: Rupiah, Real, Rupee, Lira, and Rand before and after the Fed normalization.

For practitioners, the results of this study are useful for investors to make investment decisions in emerging markets. The Fed's policy direction affects stock returns and exchange rate movements in each market. By knowing the level of dynamic correlation between the Fragile Five capital and money markets, investors can determine the right portfolio diversification and minimize the investment risks in the Fragile Five countries, primarily when global uncertainty occurs. Therefore, through this research, we also provide several recommendations as follows:

1. Investors who want to obtain benefits from international portfolio diversification in developing countries should consider Indonesia or Brazil as one of the investment destinations. This recommendation is based on DCC MGARCH results that indicate a lower correlation coefficient in both countries when paired with other Fragile Five countries. By determining portfolio diversification with the lowest correlation coefficient, investors can minimize risk amid negative sentiments such as the Fed policy normalization.

2. Further research in the future should be able to complete the analysis with additional variables outside the Fragile Five countries, for example, Argentina, whose currency was hit by the crisis in the third quarter of 2018. Also, further research could analyze the correlation between Turkish Lira and Euro currency when depreciation occurs. 


\section{REFERENCES}

Anggitawati, D., \& Ekaputra, I. A. (2018). Foreign Portfolio Investment Flows and Exchange Rate: Evidence in Indonesia. Emerging Markets Finance and Trade, 1-15.

Al Nasser, O. M., \& Hajilee, M. (2015). Integration of emerging stock markets with global stock markets. Research in International Business and Finance, 36, 1-12.

Bala Sani A.R., \& Hassan A. (2018). Exchange Rate and Stock Market Interactions: Evidence from Nigeria. Arabian Journal of Business and Management Review 2018, 8:1

Dash, A. K., \& Mallick, H. (2009). Contagion Effect of Global Financial Crisis on Stock Market in India.

Engle, R.F. (2002) Dynamic conditional correlation: a simple class of multivariate generalized autoregressive conditional heteroskedasticity models. Journal of Business and Economic Statistics, 20 (3), 339-350.

Federal Reserve System. (2018). FOMC Communications related to Policy Normalization. Retrieved October 9, 2018 from Board of Governor of the Federal Reserve System: www.federalreserve.gov

Goetzmann, W. N., Li, L., \& Rouwenhorst, K. G. (2005). Long-term global market correlations. Journal of Business, 78(1).

Markowitz, H. (1952). Portfolio selection. The journal of finance, 7(1), 77-91.

Reilly, Frank K. And Keith C. Brown. (2012). Investment Analysis \& Portofolio Management, Tenth Edition. USA: South-Western Cengage Learning.

South China Morning Post. (2018, September 6). Why the 'Fragile Five' emerging market currencies have alarm bells ringing again. Retrieved October 17, 2018 from https://www.scmp.com

The New York Times. (2014, January 28). 'Fragile Five' Is the Latest Club of Emerging Nations in Turmoil. Retrieved December 26, 2018 from https://www.nytimes.com

Tuna, G., \& Tuna, V. E. (2016). Reflection of the cointegration relation among the stock markets on the portfolio choices: An empirical application for Fragile Five countries. Ekonomski horizonti, 18(3), 187-199.

Valadkhani, A., \& Chancharat, S. (2009). Dynamic linkages between Thai and international stock markets. Journal of Economic Studies, 35(5), 425-441. 